Meta

Journal des traducteurs

Translators' Journal

\title{
Jordanian Folkloric Songs in Translation: Mousa's Song They Have Passed by Without a Company as a Case Study
}

\section{Bakri Al-Azzam et Aladdin Al-Kharabsheh}

Volume 56, numéro 3, septembre 2011

URI : https://id.erudit.org/iderudit/1008333ar

DOI : https://doi.org/10.7202/1008333ar

Aller au sommaire du numéro

Éditeur(s)

Les Presses de l’Université de Montréal

ISSN

0026-0452 (imprimé)

1492-1421 (numérique)

Découvrir la revue

Citer cet article

Al-Azzam, B. \& Al-Kharabsheh, A. (2011). Jordanian Folkloric Songs in Translation: Mousa's Song They Have Passed by Without a Company as a Case Study. Meta, 56(3), 557-578. https://doi.org/10.7202/1008333ar

\section{Résumé de l'article}

La traduction des chansons traditionnelles folkloriques constitue un domaine de recherche qui s'écarte sensiblement de celui du transfert interlinguistique et interculturel en général, notamment de l'arabe à l'anglais. Le présent article porte sur la chanson d'Abdu Mousa, dont le titre est marren wa ma mahin hada (ils sont passés sans être accompagnés), comme exemple des défis posés par la traduction de ce type de chanson. Il montre jusqu'à quel point le traducteur a une marge de manoeuvre pour reformuler l'apport linguistico-culturel du texte de départ, lorsqu'il travaille avec des cultures dont les discours présentent d'importantes divergences. Se basant sur la stratégie Pentathlon de Low (2005a) et mettant l'accent sur le contenu, l'étude met en relief les difficultés et les problèmes inhérents à la traduction de ce genre de chanson et souligne un certain nombre d'aspects qui lui sont uniques (éléments de sens, idiomaticité et références culturelles, ainsi que les rapports entre ces éléments). Au-delà de la difficulté inhérente à la traduction de ce genre lui-même, elle rend compte des difficultés insurmontables liées aux différences linguistico-culturelles et conceptuelles de l'arabe et de l'anglais. Enfin, à un niveau moins formel, le ton familier du texte source ne fait que compliquer le processus de traduction.
Ce document est protégé par la loi sur le droit d'auteur. L'utilisation des services d'Érudit (y compris la reproduction) est assujettie à sa politique d'utilisation que vous pouvez consulter en ligne.

https://apropos.erudit.org/fr/usagers/politique-dutilisation/ 


\title{
Jordanian Folkloric Songs in Translation: Mousa's Song They Have Passed by Without a Company as a Case Study:*
}

\author{
BA KRI A L-AZZAM \\ The Hashemite University, Zarqa, Jordan \\ bakri@hu.edu.jo
}

\author{
ALADDIN AL-KHARABSHEH \\ King Saud University, Riyadh, Kingdom of Saudi Arabia \\ akharabsheh@ksu.edu.sa
}

\section{RÉSUMÉ}

La traduction des chansons traditionnelles folkloriques constitue un domaine de recherche qui s'écarte sensiblement de celui du transfert interlinguistique et interculturel en général, notamment de l'arabe à l'anglais. Le présent article porte sur la chanson d'Abdu Mousa, dont le titre est marren wa ma mahin hada (ils sont passés sans être accompagnés), comme exemple des défis posés par la traduction de ce type de chanson. II montre jusqu'à quel point le traducteur a une marge de manœuvre pour reformuler l'apport linguistico-culturel du texte de départ, lorsqu'il travaille avec des cultures dont les discours présentent d'importantes divergences. Se basant sur la stratégie Pentathlon de Low (2005a) et mettant l'accent sur le contenu, l'étude met en relief les difficultés et les problèmes inhérents à la traduction de ce genre de chanson et souligne un certain nombre d'aspects qui lui sont uniques (éléments de sens, idiomaticité et références culturelles, ainsi que les rapports entre ces éléments). Au-delà de la difficulté inhérente à la traduction de ce genre lui-même, elle rend compte des difficultés insurmontables liées aux différences linguistico-culturelles et conceptuelles de l'arabe et de l'anglais. Enfin, à un niveau moins formel, le ton familier du texte source ne fait que compliquer le processus de traduction.

\section{ABSTRACT}

Folkloric song-translation is a research area that diverges acutely from the centre of interest of interlingual-intercultural transfer in general, and Arabic-English translation studies in particular. This paper attempts to shed light into Abdu Mousa's culture-bound song marren wa ma ma'hin hada (they have passed by without a company), as an instance of the challenges that folkloric songs may pose in translation, and how, when translating between cultures with different discursive properties, the translator has a certain leeway when reformulating the lingual-cultural import of the source text for target readers. Drawing on Low's (2005a) Pentathlon Approach, and placing a strong emphasis on content, the study highlights the problems and difficulties involved in translating this type of song, and demonstrates a number of unique aspects of translating folkloric songs, which involve elements of sense, naturalness, cultural references, and how these elements are interconnected and entangled with each other. These insurmountable difficulties are accounted for by the existing sharp linguistic and cultural differences between Arabic and English, and, the incompatibilities between the two working concept systems of the two languages, which add to the intricacy of translating this type of literature. On a less formal level, colloquialism has been found to have had its way to the source language text, a factor which further complicates the abridgement process. 


\section{MOTS-CLÉS/KEYWORDS}

chansons folkloriques, paroles, stratégie Pentathlon, traduction de chansons, expressions familières

folkloric song, lyrics, Pentathlon Approach, song translation, colloquialisms

\section{Introduction}

Cross-cultural knowledge transfer and intercultural communication can be considered the common core of any chromatic translatory action. Such a transfer is normally made with a specific purpose in mind and potentially involves a change of sign, code, or semiotic system from the written to the spoken (e.g., songs and lyrics), from the spoken to the written (e.g., subtitling), from the visual to the spoken (e.g., audiodescription), and many other hybrid types of translation and interpretation (see e.g., Chaume 2004: 16; Gottlieb 2003: 167). With this conception of translation, it is possible to accommodate and describe a transfer from the written to the spoken. Oral transmission is invariably and inevitably superior to its written competitor, as the latter does not usually survive intact (Raffel 1986: 12). Therefore, it is no wonder that, at present, there is a scholarly interest gravitating towards the center of translation in its oral mode. Indeed, the transmission of songs and lyrics can be unequivocally considered instances of this compelling drive. However, it is not our intention to diminish the importance of the written word, neither in original texts nor in translations. All we wish to accomplish is to contribute to a broader understanding of the field of translation, so that the various features of interlingual-intercultural translation so often discussed in translation studies will stand out more clearly against a background of translation in its totality. A working definition of folkloric songs may run as follows: folkloric songs, which constitute a major subdivision of oral literature in the field of folklore, are traditional, popular songs that correspond to the written productions of poets and novelists. This type of song circulates by word of mouth, and, sometimes, they happen to be without known authorship. Translating folkloric songs is surely not an everyday phenomenon. Its complexity makes it an extremely interesting field of research, and makes it an appropriate touchstone for translatological insights.

Vocal translation is an imaginative enterprise that purports to achieve "a translated symbiosis of poetic and musical texts" (Gorlée 2005: 8). Such an enterprise can be envisaged as logocentrism and musicocentrism, with "the relative artistic weight and importance given to either element of the double symbiotic construct" (Gorlée 2005: 8). According to Gorlée (2005: 8), logocentrism can be looked at as an approach defending the general hegemony of the word in vocal music, whereas musicocentrism is its opposite; that is, musicocentrism is a "wordless approach" (Gorlée 2005: 8). Langer expresses her musicocentric view that

when words and music come together in song, music swallows words; not only mere words and literal sentences, but even literary word-structures, poetry. Song is not a compromise between poetry and music, though the text taken by itself may be a great poem: song is music. (Langer 1953: 152; quoted in Gorlée 2005: 8)

Langer also advocates that the verbal text is annihilated and transmogrified, via a process known, rather euphemistically as the principle of assimilation, into a musical text. However, Gorlée considers such a musicocentricist view a sort of wild imagina- 
tion, as one could counteract Langer's argument by adopting the opposite position that

the composer in the process of taking total possession of a poetic text (regardless of its aesthetic quality) and of imprinting his own music on it, saves the verbal text from oblivion but at a cost: the focus on music is always to the possible denigration of the particular character or quality which any original poem, however mediocre may have in and by itself. (Gorlée 2005: 8-9; see also Anderson 2005; Fernandez 1978; Gorlée 1997: 237; Saleh 1978)

Song-translation entails not only relaying the SL message (and arguably the SL style) to a target audience in the highest possible degrees of optimality, but also subjugating the TL message to some of the musical aspects of the SL song, thereby achieving a translation symbiosis that encompasses the poetic and musical aspects (Drinker 1950; Apter 1985; Graham 1989; Whissell 1996; Dunbar 2002). Despite this proviso, the musical aspect does not fall beyond the scope of this paper, as the focus will largely be on the analysis of both the written and musical aspects of translating the lyrics constituting these songs (for fuller accounts on the translation of the musical aspect, see Spaeth 1915; Strangways 1921; Emmons 1979; Gorlée 1997; Golomb 2005). This is quite similar to dealing with those songs that are logocentrist, i.e., in which words are important and the music only serves as a background. In songs meaning remains a crucial criterion, except in some exceptional cases like nonsense songs, but the definition of acceptable accuracy can be wider here than in other types of translating (Low 2005a: 193-195). In this vein, Shunnaq and Abul-Kas (1998: 151) stress that when translating folkloric songs is meant for singing, the translator focuses on form whereas when the content is the aim, the form is relegated to a secondary position, as the focus is shifted to the meaning of the original, and so the text can be transformed from "rhymed verse into free verse or prose" (Shunnaq and Abul-Kas 1998: 151). Obviously, it is not unacceptable to translate more freely to adjust the text to the culture of the TL or to the music (depending on the purpose of translation).

Although much has been written on translation in recent decades, very few titles (e.g., Shunnaq and Abul-Kas 1998) have been concerned with song-translation, let alone lyrics-translation as such. Surveying the literature shows a remarkable paucity of studies from Arabic-English translation studies perspective in particular. This might generally be attributed to the difficulty associated with not only translating culture-bound songs per se, but also with the daunting task of re-formulating the song in question with a view to maintain other concomitant prosodic features, which further complicates the job of the translator (for details on the cultural aspect, see Asad 1986; Clifford 1988; Clyne 1994/1996; Gudykunst and Young 1992). Most of the available references do not go beyond addressing the songs' themes (see al-'Amad 1969; Rosenbaum 1983; Stocks and Maddock 1992).

Specifically, Arabic folkloric songs and lyrics received scanty attention in translation, owing perhaps to the multiple dimensions of this type of interlingual-intersemiotic transfer. Shunnaq and Abul-Kas (1998) initiated the research desideratum to describe the problems and difficulties involved with this type of multidimensional translation (in that the target text may be presented in both written and / or oral form), but unfortunately, this avenue of research still appears not to have made its entry into the field of song- and lyrics-translation (for a thorough discussion on the so-called multidimensional translation, see Gerzymisch-Arbogast 2005; Gottlieb 
2005; O'Hagan 2005). It is hoped that the present study will stimulate scholarly interest in this neglected area as to be the seed for further reflection and exploration. To give a broader view, the present paper will discuss a number of elements and theories relevant to translating songs and music because the latter constitutes a type of translation that is crucial to practising song-translating.

\section{Song-translation in a nutshell}

\subsection{The Pentathlon approach}

According to the Pentathlon Approach advanced by Peter Low, song-translating is considerably different from, for instance, poetry translation, because the verbal and non-verbal messages ought to be transmitted simultaneously (Low 2005a: 187). Obviously, capturing the verbal and non-verbal messages simultaneously does seem to be an intricate task which puts translators under tremendous pressure. To this effect, Low (2005a: 185) neatly states that "the making of singable translations is a very complex skopos, because the target text must fit the pre-existing music - its rhythms, note-values, phrasings and stresses - while still retaining the essence of the source text." Thus, it is pretty conceivable that reaching or devising skopos is the priority of the priorities for the translator. Hans Vermeer's skopos theory boils down to the notion that translators should be aware of the purpose of the target text they produce, and that they should try to attain that goal. Low introduces the Pentathlon Principle,

a deliberate balancing of five different criteria - singability, sense, naturalness, rhythm and rhyme. This balancing should be central to the overall strategy and also a guide to microlevel decision-making. Translators are warned against any a priori view that identifies a single feature of the source text as absolutely sacrosanct: the more margins of flexibility available, the greater chance of a successful result. (Low 2005a: 185; for more relevant details, see also Low 2002; 2003a; 2003b; 2005a; 2005b)

Considering the fact that sameness in translation is an impossible task to achieve, Low compares the five criteria to the five events of the athletics pentathlon. The athlete cannot win all events combined; rather, s/he is required to perform very well on all events to win overall. If the athlete realizes s/he cannot score high on one of the events, s/he ought to compensate this with a better score on another event in the same chain. Likewise, if the translator, for example, cannot maintain the original rhythm, s/he might sacrifice a few rhymes. This strategy should also be used in microlevel decisions: "choosing which of several possible words or phrases is the best option overall” (Low 2005a: 191).

\subsection{Kaindl's approach}

Rather than propounding on how to go about song-translating, Kaindl (2005) primarily focuses on non-verbal elements, like music and video, on cultural elements involved in translation, and on music as a system. According to him, meanings in music are conveyed through verbal texts as well as through musical and visual signs, such as music, video clips and CD booklets. He regards every part of the production and reception of a song as relevant for the translator. Kaindl does not advocate a song-translation model of his own; rather, he draws on what Philip Tagg puts forth. 
Tagg (2000) proposes the use of a "hermeneutic-semiological method," which can, according to Kaindl, "also serve as a starting point for a translation-relevant analysis":

- aspects of time (e.g., tempo, metre, rhythm);

- aspects of melody (e.g., timbre);

- orchestration (e.g., instrumentation, voice type);

- aspects of tonality and texture (e.g., harmony, relationships between voices and instruments);

- dynamic aspects (e.g., audibility, accentuation);

- acoustical aspects (e.g., distance between sound source and listener, simultaneous extraneous sounds);

- electromusical and mechanical aspects (filtering, compressing, phasing, distortion, mixing).

(Tagg 2000; quoted in Kaindl 2005: 245-246)

\subsection{Franzon's approach: fidelity and format}

In a very interesting article entitled Musical Comedy Translation: Fidelity and Format in the Scandinavian My Fair Lady, Franzon (2005) distinguishes between two notions fidelity and format, with the assumption that "in song translation, adaptation may well be the only possible choice" (Franzon 2005: 265). According to him, "[f]idelity (of some kind) is what distinguishes a translated song from all-new lyrics to old music. Formatting is what may transform a useless (literal) lyric translation into a singable and performable one" (Franzon 2005: 266). Thus, fidelity is a form of a literal translation of a song, and format is the practice that qualifies it for performance, i.e., fidelity is the rendering of the entire verbal components of the SL, while formatting is concerned with non-verbal elements which make it presentable.

Ernst-August Gutt offers a similar idea for which he coined the term direct translation instead of fidelity. Gutt (2000: 135) states that direct translation calls for the preservation of "all the communicative clues of the original" which would enable the receptors to arrive at "the intended interpretation of the original, provided they used the contextual assumptions envisaged by the original author" (Gutt 2000: 135). This notion of translation seems pretty convenient for the preservation of stylistic features in the sense that communicative clues "reflect not only the information content of what was said, but also the way in which it was expressed and the special effects that such stylistic features would achieve" (Gutt 2000: 135). Franzon sees that using the contextual assumptions envisaged by the SL communicator can often be an unattainable goal, a problem that may be resolved by a more flexible form of fidelity being referred to by Gutt as indirect translation. This type of translation sanctions producing a TLT that is as close to the original as possible. This approximation is confined only to those respects that can be expected to make the TLT adequately relevant to the receptor language audience. Finally, in connection to the coherence of the text with the musical information, Franzon raises three questions:

- Does the text make the music meaningful (in terms of musical expression, arrangement, connotation)?

- Does the text rhetorically suit the music (in terms of harmonic progression, strophic structure, focus on certain words and phrases)?

- Do the phrases prosodically fit the music (in terms of intonation, stress, vowel quality)?

(Franzon 2005: 293) 


\section{The present study}

Songs and lyrics have an umbilical relationship with culture, which can have an immediate and considerable impact on the skopos of the translating mode. Thus, from a translatological point of view, the skopos of rendering a song may not necessarily be communicating the content; rather, it could be singability, rhythm and rhyme. Thus, the objective of this paper is twofold. First, the study attempts to introduce the prospective TL audience to the interlingual-intercultural differences between Arabic and English, which emanate from translating the lyrics that make up the fabric of these songs. Such differences are very likely to result in incompatibilities that will raise translation problems that need to be solved when re-formulating the target product. This is crucial as to enable re-creating the experience of reading or listening to the Arabic original for non-native audience through a communicative reproduction into English of the informativity, profoundity, and beauty of such songs and the pleasurable reaction their semantics induce. Second, given the current clear paucity of research in this domain, the study seeks to ascertain that song-translation is possible, and so this constitutes a promising line of work with possible areas of investigation that should be given due attention. In other terms, this is an exploratory study offering a ray of hope and an inspirational-zealous attitude calling for the revival of research in this little explored area.

Having these two objectives in mind, the study concentrates in its selection of the authentic examples on a song that combines both the logocentric and musicocentric properties. In translating such type of songs, the translator should pay equal attention to sense and singability. Indeed, understanding the content of the songs' lyrics is not enough to produce a singable translation, as the translator ought to be mindful to the sound symbolism of the song as well. This means that, apart from the characteristics of the source-text sequence, the individual translator and his or her specific choices are the most decisive factor in the translation of the lyrics of a given song. Naturally, this type of translation seems to gain phonic-communicative momentum in genuinely culture-bound texts. A prominent culture-bound text type is the lyrics of Abdu Mousa's songs. The reason why choice has rested with Abdu Mousa's song marren wa ma ma'hin hada (they have passed by without a company) is that Mousa's songs are undoubtedly very influential songs in the history of Jordanian music, and still very popular today. His songs still appeal to many people because of the simple fact that many of them were remarkable songs with rich lyrics and captivating melodies and rhythms that critics will probably never cease to discuss. Because their lyrics are powerful and in any case provide a view of what was going on in the sixties and seventies, it is still interesting to look at them.

Accordingly, Low's Pentathlon Approach is probably the only one of the abovediscussed models that sounds fairly adequate for the purpose of this study. Although it has its own pitfalls, it is in fact the only model that deals with translating lyrics. Tagg's model is more about translating songs, rather than translating lyrics, and therefore is less interesting for this study. It is, however, certainly very useful for practical purposes. Franzon's dichotomy of fidelity and format and Gutt's polar notions of direct and indirect translation are also very interesting, but can in fact be applied to any type of translation, and thus do not seem to offer much for translating lyrics. More specifically, the reason why the Pentathlon Approach does appear to be 
somehow useful for this study is because it embraces most of the aspects a translator should take into account when translating lyrics. As Low elaborates, all features, except rhyme, are duties towards those involved in the translation process. It follows that sense, naturalness and rhyme account for the writing of the lyrics, while singability and rhythm deal with the fact that the text should fit the music. Under the Pentathlon Principle, the translator attempts to score as good as possible on each aspect, rather than getting a top score on one aspect and a low score on another. Under sense, Low says that sense might be slightly adjusted so that the words fit the rhythm. However, under rhythm he explains that the melody may be altered to create a better meaning or word order possible.

This seems paradoxical, but the choice between sense and rhyme is based on another choice, which the translator has to make before starting to translate a song: the question whether the song is musico- or logo-centric. It may also be argued that naturalness comes along with sense, because if the translator desires to put something into words, he/she will probably also opt for expressions that are not too difficult to understand, and words that fit the register. In that case, only two criteria would remain: sense and naturalness. However, to be able to provide more precise comments on the selected examples, the study will, where necessary, touch on the other criteria as presented by Low. All the examples used here are authentic and come from the authors' own translations. In the examples offered, special importance will be placed on functional, communicative, or pragmatic translation, rather than literal or formal translation.

\section{Discussion}

At the outset, it is useful to provide the song in Arabic, followed with an over-literal translation. Towards the end of the discussion, there will be an attempt to produce a much more polished singable translation that tallies with the suggested model, the Pentathlon. Here is the Arabic song together with a crude translation in English:

(1) Oh dearest friend: they have passed by on the dew's trace,

With thin waists and the eye is blacklined

Like doves, on the water flowing point they came down

With blond hair, on the shoulders braided

They have passed by gently, gently without anyone with them,

Walking on the trace of dew and that of chill

The air blew and played with the strands of their hair,

With their consent, it held their silky hair

They are similar in height and age And slowly walk like the does of deserts

Haven't I told you my heart to follow their fancy,

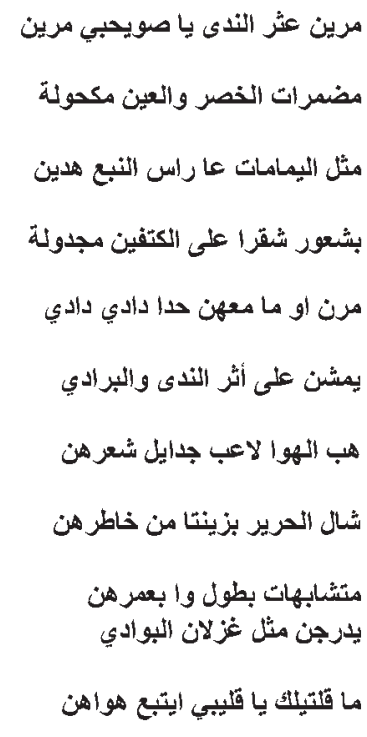


As all good luck and blessings walk with them

They speak in signs and you know their lingo,

Oh, dear heart, obey fancy and why stubbornness

Oh dearest friend, do not blame a lover,

As he walks in the desert and wipes his tears with his clothes

The moon of lovers emerged and its stars have appeared,

And oh my eye, remain vigilant till I achieve what I aspire to

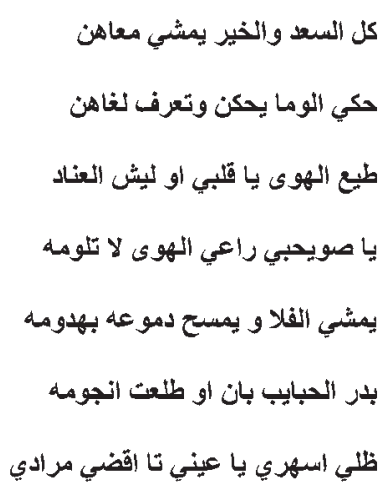

Translating Jordanian folkloric songs into English is a hard task, not only because of their cultural idiosyncrasies, but also because of the peculiar stylistic aspects they show. Embellished by many idiosyncratic values pertaining to the rustic and bucolic Jordan, Mousa's songs gave themselves inimitable eccentricity and exclusiveness that cannot be ignored in translation. In order to highlight the challenges arising from translating this type of literary genres, one of Mousa's songs is interlingually and interculturally discussed and analyzed, as to pin down some translation problems characteristic of this type of popular literature. The song, marren wa ma ma'hin hada (they have passed by without a company) is believed to exhibit linguistic, psychological, emotive and socio-cultural translation problems. The rationale behind choosing this song is that it clearly reflects the Jordanian community in the late sixties and early seventies. Moreover, its translation into a completely different or even contrasting culture is likely to lead to many problems due to the eccentricities it embraces. In addition, the Jordanian community was highly fascinated by this song, and it was till very recently part of their daily chanted lyrics, as it echoes their social heritage. It should be pointed out here that folkloric songs address certain themes and may not go beyond these themes (see Rosenbaum 1983; Stocks and Maddock 1992). For spatial limitations, some themes of the song are explored and an attempted translation is suggested as to show the real translation challenges that such type of a chanted song may pose.

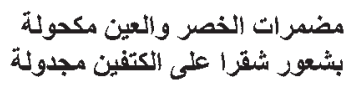

Starting his songs with the rebec, Mousa seems to have succeeded in producing enough effect on the audience and stimulating their feelings, especially those who share similar experiences and have hilarious ears. The fact that the North of Jordan and the South of Syria have a lot in common helped Mousa perform the song in a way that reflects a large part of the area's idiosyncrasies and pictorial images. Such reflections are not easily imitable in the same language, and could be untranslatable in the target language, due to their deeply-rooted characteristics in the source language, on the one hand, and the vocalist's additives, on the other. Moreover, the music that accompanies the song forms a considerable part of the presentation, where verbal and non-verbal messages are conducted, a fact that conforms to the Pentathlon Approach, which stresses the intricacy of the translation task. The verbal and non- 
verbal parts of the sung text are interrelated and preserving any of the textual parts in translation is deemed to be at the expense of other parts. The rhyming and rhythmic constituents which add beauty to the original written and then sung text cannot necessarily be obtained likewise in the target language if the translator does not digress from the text literality. What adds to the complication of translating this folkloric song is the mawwal (folk song in colloquial language), as a warming up portion that incurs in the audience a real intention to lie in wait for the folkloric stream of skillfully intertwined images. Moreover, vowel lengthening of the song gives Mousa enough breath to render the words to sway not only with the sound of the rebec, but also with the wavy movement of the audience, and this leads to the superiority of oral transmission of a text over its written form (Raffel 1986: 12).

Translating the first two lines of the song into English collides with the cultural heritage of the text. In the Jordanian culture, water-carrying women fill jars in the morning when weather is moderate, and they tend to do the job in groups. The beautiful scene that they draw is the approximation in age, height, dress, body structure, and even the way of speech and behavior, a rural excellence that gives them the potential to understand their own sign language. Therefore, rendering the two lines as

(3) Oh dearest friend: they have passed on the dew's trace, with atrophied waists and black-lined eyes,

Like pigeons when perching on the water flowing point, with blond hair, braided on the shoulders

conveys the literal meaning of the text, but fails to relay other cultural associations. In the source text culture, an atrophied waist is an elemental feature of beauty that credits ladies with an endurable attraction power that with spears targets ambitious looking eyes. In other words, such waists are not soft and limp and are thus worth feasting one's eyes on. This naturalness of the original text and the smooth flow and flexible voweling and word structure, together make it a hard task for the translator to reproduce in the target language. The singability of the source text can only be achieved if the translator deviates the literality of the text by having singable words, though non-existent in the original text. On this basis, the Arabic lexical items marrein, they have passed, and haddein, 'they have perched,' which constitute the first two hemistiches of the first two lines of the song are singable because of enjoying enough rhyming, rhythmic, and phonic features; the same applies to the second hemistiches of these two lines, where makhouleh, black lined, and majdouleh, braided, are singable but cannot be likewise when translated into English as blacklined, and braided. The compensation of the rhyming and rhythm loss can be achieved by reproducing a singable target language version. In this regard, Low (2005a: 185) states "the making of singable translations is a very complex skopos, because the target text must fit the pre-existing music - its rhythms, note-values, phrasings and stresses - while still retaining the since of the source text." Accordingly, the singability of the source text can be obtained only if deviation is made from such a text as shown in the second non-literal translation which is provided in the study, a translation strategy that is licenced in the translation of literary genres such as poetry and songs.

What led Mousa to bite his lips in adornment and appreciation of the countryside women is the svelte bodies and the basil height, which are merits that the other sex 
overestimates. These cultural marks of beauty are drawn from the ladies walk, where modesty breeds more appreciation. He shows humbleness, submission, and humiliation to the women group by addressing someone absent, when he used the diminutive form, isweihibi ( $m y$ dearest friend). He tries to show his love weakness to the addressee by not mentioning explicitly what is captivating him, and repeating some clauses such as مرين (they have passed by). The use of diminutive forms and the repetition of some clauses are functional in the source text; however, they are impractical and redundant in the target language, as they do not create a similar effect on the receptive language audience, a fact that results in considerable translation loss. In addition, the socio-cultural dimension of the source text cannot be maintained in the translation, as what makes those women witty, full of esprit, and nimble is life in the countryside, where women are responsible for supplying their homes with water, a role that shapes their structure and refines their behavior.

The destination arrival methodology of the ladies is also important and creates a peculiar understanding for the people who are desperate for water, especially during summer. Bringing water for drinking, cooking and cleaning is the utmost ambition of the countryside dwellers, where women are in charge of doing this duty. Mousa illustrates the fact that the ladies tend to fill jars with very pure water; in other words, they choose to fill up from the springing point of the stream, a tendency that shows their disgust to drink from other fillers' drinking places. Translating the above part of the lyric into English is hard and deprives the translated version from many source text cultural and social features which form a large part of it. Describing the ladies at the stream arriving moment is so animated and communicative, but this animation cannot be equally apparent in the target language, as illustrated in

(4) They are like pigeons when perching on the water flowing point, with blond hair, braided on the shoulders.

The flexible structure of the song enables the composer to croon it in a strikingly amusing way, a source text feature that validates the singability of the song, as one of the Pentathlon's parameters.

In the Jordanian culture, woman's hair color and style are components that complete her beauty and character; enjoying long, blond and braided hair stimulates Mousa to successfully describe the countryside ladies filling jars on the brook. In the target culture, where people are too familiar with this type of hair, the image drawn in the source text looks normal if not nonsense. This cultural contrasting view of the two texts may give rise to misconceptions on the part of the target language readers, which, in turn, strips the source text from its amusement function. Whereas the audience of the source text is entertained by the lyric of Mousa, and the way of performance, the target language audience does not pay a due attention as what looks emotive and arouses feeling in the source text might be sensed as normally and incidentally. What adds to the striking panorama is the hanging braided hair on the shoulders of the ladies; this waterfall-like scene of hair addresses the madly-in lovefalling hearts, and cannot be hypnotized to the same extent in the target language, due to people's familiarity with the hair and the setting.

Mousa continues the song and describes how the ladies start their daily trip to the fountain. What gives him the opportunity to satisfy his looks with the unaccompanied ladies and portray them from head to foot is the belief that their male 
relatives are not existent in the place. The modesty of the ladies is illustrated in the way of their walk; their beauty is felt when the breeze dallies with the wisps of their hair; and their water time is associated with the temperate moments of the day. These source language components are very essential in building up the song and creating a tantamount audience heart reaction. Thus, such associations gave Mousa the capacity to create a social setting that is inimitable not only in the source language community, where neither the audience nor the rebec player can recreate, but also in the target language community that enjoys a conflicting outlook to the world. It can be inferred from this discussion that Mousa finds it a good opportunity to observe the ladies going by themselves to the water resource, and as such succeeds in brilliantly describing the whole scene. Listeners and readers of the source text can make out the happiness of Mousa, and discover the utmost glee while depicting the activity, as they together feel the beauty of the song as a chanted lyrical material that displays rhythm and rhyme according to the Pentathlon Approach, which cannot be recreated to the same degree in the target language. The sacrifice of the source text literalness and sense is compensated in the supposedly sung translation which is provided in the study; this concords with Low (2005a: 191) who states that choice of several possible words or phrases is the best option overall.
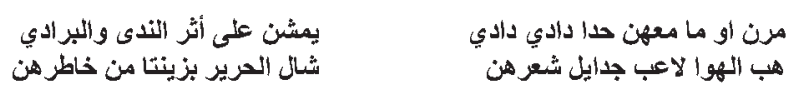

Rendering this couple of lines in English as

(5b) they have passed by gently (gently) without a company, walking on the trace of dew, at temperate moments; the air blew and stroked the wisps of their hair, With their consent, it held their silky hair

does not allow the translation to go through easily for cultural, linguistic, literary, and social reasons. Generally, song translation loss can be attributed to the fact that it displays the style and features of its people's lives, their tight link with the land on which they flourished, and the natural surroundings with which they communicated. The folksong discourses people's real life situations, and therefore enjoys great popularity; its artistic value stems largely from its tune, where the literal meaning in translation is given a lesser importance. The simplicity of the countryside life helped Mousa to choose words that can effectively fit and suit the situation. One of the translator's main objectives is to preserve the sense of the source text, which can be clearly noticed in the translated version, where the meaning is grasped by readers. It might be true to claim that the readability of the receptive language text gives it its naturalness and sense, as this complies with the grammatical and syntactic rules of English. Relaying this feature of the source text concords with one of the Pentathlon's approach aspects though at the expense of other features such singability, music and rhyme and rhythm. Music itself contributes in the totality of the whole song and is integrated with its rhyme and rhythm. The Arabic lexical items dadi, gently, dadi, gently in the first line, and sha'irhin, their hair, and kahdirhin, their consent, are singable and attentive in the source text, because they have enough rhyming beauties; however, their translation, respectively as gently, gently, their hair, and their consent 
cannot preserve the musicality and singability because of lacking rhyme, rhythm, and singability features that can be compensated only if the translated version is provided with lexical items that are basically singable and at the same time that can preserve meaning, content and naturalness that the target language readers can approve.

In other words, a sacrifice of the aspect of singability is made as to maintain the aspect of sense of the source song; yet, delivering a singable translation is manageable if the translator deviates from the literal composition of the source song and yields a text that embraces many singable features such as rhyme and rhythm. Preserving the source text characteristics in translation can, thus, help in balancing it with its counterpart, a criterion that the Pentathlon approach has called for.

The singer attempts to joke with the ladies by describing their gentle and soft movement, through the repetition of the Arabic lexical item دادي (gently gently). This song colloquialism has gained considerable currency in the Jordanian Arabic. Hence, repetition of the same colloquial word in translation strips the beauty from it, and may produce an uncomfortable sense on the target text observant. In other terms, the repetition of this particular lexical item is functional in the source song, as it simplifies the flow of words utterance, and exposes the ladies when playing the dandy. On this basis, babying the ladies and describing their appreciated deer-like walk is exclusive to the source text, and may prove difficult to be correspondingly grasped in the target language.

Ecologically, Jordan is featured by hot summer days. This necessitates that the ladies should bring water either in dewy mornings or in moderate evenings. These two portions of the day are crucial, as farmers gather crops and pluck vegetables. All people, males and females, young and old tour the cultivated land to pick vegetables. This ceremonial time of the day is clear and emotive in the source text to the extent that the audience becomes quite enthusiastic over the sung words. In the target text, however, similar feelings cannot be produced on the audience as the weather is reasonable most of the year, and ladies do not practise similar daily activities. In other words, the rural climate and the seasonal workshops of the source language culture cannot be reflected in the target home-provided facilities culture, where ladies are business-oriented and do most of the jobs in indoor offices. Moreover, modernization of the target text is likely to make the Jordanian ladies' daily activity in the late sixties and early seventies look alien, odd, nonsensical, and, more importantly, less emotive.

Rendering هب الهوا لاعب جدايل شعرهن شال المريز بزينتا من خاطرهن into English as the air blew and strokes the wisps of their hair, held their silky hair for their very sake creates translation challenges. Women of Mousa's time tended to boast with their long pony tail hair style as a characteristic of beauty that not all ladies can win. This type of hair, falling over ladies' shoulders, was greatly admired at that time in most parts of the country. Mousa succeeded in producing a power of entertainment on the audience that was sharing with him similar social and cultural experiences. In the target culture of today, where ladies have different hair styles exemplified in dyeing and cutting their hair, the source text beauties are not similarly appreciated, a fact that results in translation loss at many linguistic and cultural levels. This can be linked to the translator's motivations which are inextricably bound up with the socio-cultural context in which the act of translating takes place (Hatim and Mason 1990: 12). Translation loss crosses cultural and linguistic borders to include loss of sound and 
rhythm. Translation of songs focuses on literal rendering of the meaning of the source text, a translation approach that neglects or fails to preserve its other unwritten aspects. The musicality of the song lies in the extremes of the two hemistiches, where the last words have the same weight, as shown in the line above. This musicality, which forms a substantial part of the whole song, is one of the Pentathlon Approach components, and can only be obtained in the receptive language if the translator searches for words that can have the same language verbal power, and exploits the margins of flexibility available for him/her that can give a greater chance of a successful result (see Low 2002; 2003a; 2003b; 2005a; 2005b).

The intimate relationship between people and the place of living is plain in Mousa's song. This intimacy generated a solid bond between the ladies and the countryside elements of the North Jordan. The gentle touch and the light stroke of the breeze over the ladies' hair signals the warm feeling created as a result of the long familiarity between the two. This picturesque image is successfully achieved in the source text, as the composer of the words, and the singer of the lyric are deeply steeped in the environment. Gently as one can imagine, the breeze hesitantly plays with the ladies' silky hair, as the rural community is reserved and does not allow the hair which is a private part to be seen, let alone being played with. This image is very striking on the audience of the source song, and becomes more striking when accompanied by the tune of the rebec which adds to the forcefulness of inimitability in the target language. Furthermore, the image of the breeze shyly playing with the hair is tangible to the extent that it complies with the ladies' feelings. This picture cannot be reproduced in the target language where covering hair is quite odd and loosening it is also admired. This difference in the social view, which gives rise to many translation problems, results from the two varying cultures and settings and cannot be bridged without giving the receptive language reader enough awareness about the values and norms of the source language song and its setting.
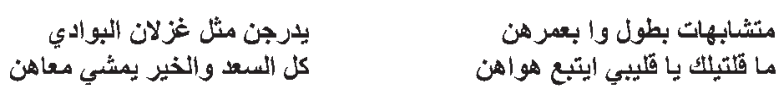

In many parts of the song, Mousa tries to express the harmonious relationship between the ladies not only in the talk, but also in behavior, the time of bringing water, their complexions, dress, tone of speech and more explicitly, height and age. They share the property of height as they are genetically related in the countryside, where most people marry their relatives; they share age as ladies at a certain time are given the duty of bringing water. Synchronization is thus socially woven and normalizing it in the target language is not easily achievable. Rendering the above verse which expresses these features is possible as they are similar in height and age and gradually advance like the dunes of deserts. What is remarkable and emotive in the source song seems natural but less influential on the target text audience. The source text aims to be sung and to entertain, while its literal translation does not seem to have achieved either of these two aspects, as literal translation has robbed the text of its rhyme. The target language version does not enhance the pleasure of the reader who understands the material as an ordinary text.

The desert Oryx represents beauty in Arab culture. Such an animal is known as she-of-udder, wide-of-eyes, and flat-nosed: the more central its symbolic associations, the more epithets an animal will have. Metaphors and similes must have been honed 
and selected over generations (see Sells 1989: 5-6). This inherited significance of resemblance added more beauty to the ladies' likeness to the deer. The poet praises the females by comparing their beauty with the desert deer. This socially agreed-upon quality of beauty is forceful in the source language, but could become powerless in the target language, simply because such an animal lacks similar appreciations, e.g., red-breasted nuthatch birds or chestnut or bay horses. The translation problems of the song become more complicated if we consider the fact that its singable form is associated with the traditional musical tone, which hones the tableau of the whole scenario. Music, the words of the song, the style of performance, the voice of Mousa, the place of presentation, and the type of audience are all culture-bound, and any translation gain is achieved at the expense of many translation losses. The song is tightly linked and its parts are built on the rhyme of the long aadi from the beginning to the end. To illustrate, the two lines in question are not separable from the previous lines where dadi, baradi, and bawadi, respectively gently, chill, and desert show clear rhyming power. This rhyming power of the words ending with this long aadi, which is represented in bawadi, desert, and the rhythm of the verse, cannot be easily preserved; the same applies to hawahin, and maahin, their fancy, and with them. This inevitable translation loss of the translated song cannot be avoided unless a singable translation is provided with a clear deviation from the literal source song; a possible compensatory translation strategy for rhyming and rhythm loss is to reproduce a target language song that maintains sense, content, naturalness, and added to all these features, rhyming and rhythm that can entertain the target language reader.

Repetition of song syllables gives more power and breadth to the song itself and enriches the audience listening ear with pleasure and enjoyment. Repetition of some syllables is not shown in the source text as they become redundant, and attempting to retrieve them in translation is likely to yield an unpleasant redundancy, since a successful redundancy/repetition in one language may be outmoded and unnecessary in another. Another emerging translation problem here is related to the use of colloquialisms. Most parts of the song are colloquial and translating them into Standard English dispels their beauty. Informal language expresses the real world of the lyric, as informality and colloquialism are closer to naturalness and credibility than formality and standardization. Consequently, departing from the environment causes artificiality of the text not only in the target language standard text, but also in any presumed standard source text. In other words, translators should be aware of the register of the source text and how to preserve it in the target language; the source text colloquial expressions are proposed to be relayed as target language colloquial ones. On this basis, novice translators may be grappling with colloquialisms, especially if the need for a singable translation so demands.

The fact that Mousa's heart is captivated by the fancy of the countryside ladies induced him to link them with the blessings they could bestow. This feeling grew to the extent that Mousa let his heart follow the ladies' love, since blessing, bounty, and goodness are associated with them. The countryside scenes gave Mousa the ability to inspire and create an untranslatable chorale and the musical idiosyncrasies of the song confronts the translator with an arduous translation task, such that preserving the four criteria of the Pentathlon may look treacherous. This hallucination led the singer to address his heart while at the same time blaming it for not following the 
ladies. Translating the above line into English as haven't I told you my heart to follow their fancy, as all good luck and blessing march with them robs the source text from many beautiful and emotive images that require compensatory strategies to retain the linguistic, psychological, cultural, and musical values.

The target language male readers who can easily build love relations with the other sex, do not undergo a similar love suffering as that of the source text readers. The source text singer's burden of love is bitter enough, and helped him to utter words that fully describe his severe round-the-clock moments. Though he knows his heart dare not chase the ladies due to fear, shyness, and for other social reasons, he nonetheless blames it for abstaining from doing so. This social discrepancy of the two texts' audiences inevitably means that the extra-linguistic values suffer a real semantic-cultural loss. Addressing and imploring only his heart and uncovering his dilemma to it are cultural aspects, not only of the Arabic song composer, but also of classical Arabic poetry where poets used to start their poems on the traces of the beloved to lament her departure. It seems, then, that Mousa followed the same method though his eyes do not shed tears in recalling the love, and the lodging by the edge of the brook. His manhood does not allow him to show his mighty-firekindled-up-heart, as to so reveal would not only exposes his life to danger, but also the ladies' lives as well.
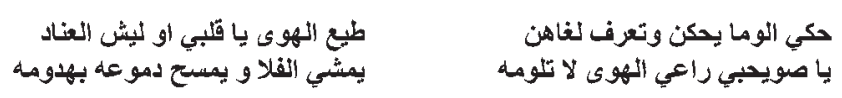

The paradoxical language of Mousa in addressing his heart to follow the ladies, and accusing it as refractory comes as a result of the successive failures of making any relationship with them. What yields the ladies greater attention is their peculiar language, which is very often based on signs. The secrecies and privacies of the ladies made this language essential to help envelope their deeds and behaviors in a reserved community like the Jordanian one. The success that Mousa achieved in describing the ladies' behavior and talk is derived from the practical experience that helped him to match the real scene on the ground with its description through words. What gave eccentricity to the song is Mousa's voice which best illustrates the whole scenario. This feature adds translation complications to the already existing ones, as full imitation of voice is unattainable even by persons living under similar environmental conditions, and enjoying similar social talents. Thus, this vocal aspect of singability is quite difficult to duplicate, and, as a result, compensation should, at least, be sought in the content of the song itself.

Translating the first verse into English as they speak in signs and you know their lingo, oh, dear heart, obey fancy and why refractoriness presents many translation challenges. The way of speech is a culture-bound behavior, as ladies in the Jordanian conservative community are not allowed to speak loudly, lest they be heard by the opposite sex and provoke passionate thoughts. This source text attribute is not understood likewise in the target language, where ladies can express what they want to say loudly and in public. The singer has succeeded in injecting his audience with what is socially appreciated; he tries in his talented voice to relay a social message that entails a publicly agreed-upon sense which goes consistently with retaining sense as one of the Pentathlon Approach principles. However, this success is considered as a shortcoming in Western Culture where society is wide open and gives enough freedom of 
many types to females, even the freedom of being in a relationship. Thus, the emotive power that is created on the source text audience is not created to even a small extent on the target language audience.

One of the main objectives of literature is conveying a message to the reader or audience, as literature depicts the society with many of its norms to the writer. What applies to any literary genre applies to songs. In the above line, Mousa tries to stress the message that ladies in the Jordanian community are characterized by shyness and gentleness, not only in their walk but also in their speech, a social quality that drove them to use sign language as a means of communication. The translator has to be aware that the sense and the way of expressing it are inseparable, and each part is complimentary to the other. Moreover, the message can be better understood if it is sung, as more repetition, currency and frequency of the song among all classes of the community, literate and illiterate, high and laymen consolidates this comprehension. The sense preservation of the song can be looked at as a balancing feature of the song according to the Pentathlon Approach.

The bitter battle between the singer and his heart is expressed in blaming the latter for not following the ladies' footsteps to the brook. Social restrictions preclude the singer from going after the ladies to the water; social cameras are focused on the entire site at this particular time of the day. The time of bringing the water home is the love opportunist's best moment to satiate his love thirst. Mousa seems to have been successful in the choice of setting to portray the social life of his time. Thus, in order to achieve some degree of emotiveness on the target language audience, the translation must take into consideration the writer's (the singer's in our case) whole world-view. Hatim and Mason (1990: 4) stress this fact by maintaining that texts flow from motivated choice, where producers of texts have their own communicative aims and tend to select lexical items that can serve their aims. The translator must therefore match and conciliate between motivations of target text producers and those of source text receivers; this endeavor is partly deemed to fail in our case where social and cultural features of both texts are plain, and cannot be easily bridged in a human effort like translation.

Consoling himself and others by addressing a non-existing friend is again a strategy that Mousa adopted to make melancholy apparent in his song. This strategy prefigures the premise of mutilation which dominates the whole song. His audience is overshadowed by the same sadness, as they are experiencing or have already experienced such paths of grief. In order to preserve manhood and save face, Mousa talks about a lover unknown to the audience, trying to exclude himself from the mêlée of love, a reference that may simultaneously add to the beauty and sadness of the source text. This is a success in itself, where his voice is embraced by the sound of his intimate traditional musical instrument, the rebec, that creates sadness by its very nature, and all the more when joined by a lovelorn singer. This sound symbolism is semantically oriented and constitutes a part of the whole scenario, as it represents the relationship between the sound of utterance and its meaning (Hinton, Nichols et al. 1994: I). In the target language culture, however, where many musical instruments are played together, the singer's voice becomes part of the whole musical noise, and cannot be separated from the musical toll. This consequently does not elucidate a major theme of the song, which is based on expressing grief and sorrow on the loss of the love or the difficulty of gaining it. 
Translation loss at many levels is inevitable when rendering the second above verse into English as Oh dearest friend, do not blame a lover, going in an open-ended land and wiping tears by his cloth. Suffering for long time without gaining what he so strongly desires, a Jordanian lover leaves his home, in the same way desert wolves howl and run in all directions. The social culture of the Jordanian community demands that parents of the girl be fully acknowledged about the noble love before one attempts to propose to her hand. If relatives do not approve the request, the journey of love pain starts, as it is not always the decision of the lovers to get married, but of their parents, and sometimes cousins, as the latter may oppose her marriage to foreigners. In the target culture, however, where ladies are given full self-determination in choosing their partners, such meanings of impositions dictated by the community are lost. Going out, talking with surrounding elements, complaining to living species, and composing sad episodes form a large part of the novel. These associated meanings cannot be grasped to the same extent due to social and cultural barriers, and can only be bridged through lengthy discussion and paraphrasing.

The emotive meanings produced on the source text audience are very influential, and derive from the way they are presented. Sad moments of the lover are expressed by the natural voice of Mousa who laments that Jordanian fully-cultured people shed tears, though they do not know who is meant in the song. Mousa expresses his grief simply but effectively with clear and natural language that avoids artificiality; this naturalness of the song expressions is preserved in the receptive language, where simplicity and flow of language can be noticed by ordinary people. Moreover, the naturalness of the text and its readability are easily observed in the target text, as target language readers can feel the sense of the composed song. This is gained, of course, at the expense of other features such as singability and rhyme and rhythm or musicality which can be guaranteed when literalness and word for word translation are avoided. Since music forms a real part of the song in the Pentathlon Approach, it guides the text and the singer in an entertaining direction that should be retained in translation. To illustrate, the Arabic lexical items laghahin, their lingo which is singingly harmonious with hawahin, their fancy, and ma'ahin, with them are singable in Arabic but cannot be similarly performed in the target language. The same applies to inadi, stubbornness, which is musically consistent with other lexical items that end the first or the second hemistiches of the song such as dadi, gently, baradi, chill, and bawadi, desert. Furthermore, the second line of this pair of the song is musical since it has a rhyming feature that is represented in la tilumuh, and bihdumuh, respectively do not blame him, and with his clothes. Loss compensation can be acheived by reproducing a singable translation that enjoys musical features such as rhyming and rhythm, though at the expense of the literality of the source text, which is a translation option that can give the translator enough space and freedom to make up for some loss. Preserving the song musicality can be achieved through the successful choice of words, though at the expense of certain features of the text, that can fully obey the music itself, the singer and the audience. The emotional aspect of the song is confined to the source text, and cannot be preserved in the translation of a literary text such as the song, where every utterance is in itself a tale of sorrow in sad songs. The sound only has meaning in that it directly reflects an internal state of the body or mind (Hinton, Nichols et al. 1994: 2). In other words, what the source text aims 
at creating is natural and reflects a real experience, while what is deemed in translation is conventional and reflects the mirage of the source text.

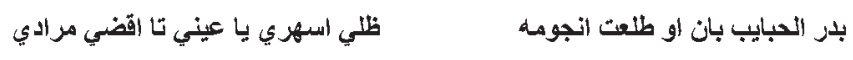

Mousa concludes his song by making clear that a lover suffers all day long and should continue suffering the whole night, since love merits such pain and agony. The moon in the Arabian culture is lovers' guide, and under night darkness they usually meet, lest they be observed by others. These connotative meanings and associations of the moon are not similarly appreciated in the Western foggy and cloudy environment, where the sun is rarely observed and the moon is even more rarely noticed. Lovers console themselves by shedding tears and wailing for their loss of love.

Translating the concluding verse into English as the lovers' moon has emerged and its stars have appeared, and thus, oh my eye, continue to vigil till I gain what I desire dispossess it from many social and cultural implications, for the following reasons. First, the significance of the moon as a guide for lovers' meeting is lost as love in the target culture is openly experienced and it is a demerit for a lover to hide his love. Second, pre-marriage love is socially and disapprovingly viewed in the source text and as such is given full secrecy. In the target culture, however, neither the relatives nor the society rejects this relation as it forms an important element of social life. Third, in the source culture, the socially unknown love is practised in outdoor places such as wooded area, water springs, or during harvest season, where a sense of cooperation is sensed in such places and times of the year. The scenario is completely different in the target culture where love is practised anywhere and at any time of year. The meaning of sorrow and limitations of place and time for practising love in the source text cannot be preserved in the target language without providing the translated text with sufficient background on the setting and conditions of composing these lines that truly portray the scene.

To listen to this song in the target language, people should experience a similar transformation and should have a similar ability of performance, as the words of the song are meant to be practically performed. Retaining this performance in translation is not trouble-free, as what is composed to be performed has many non-verbal messages that can only be transmitted through real action. Rhythm and rhyme are not easily retained in translation of songs, since naturalness, which corresponds to one of the Pentathlon Approaches, is lost through the artificiality of the receptive language song. This is clear in the last line of the song where injumuh, its stars, is tightly connected with previous words in the song that have the same musical and singable capabilities such as ihdumuh, his clothes, and la tilumuh, do not blame him, and maradi in the last hemistich which is musical with previous words in the song as $\underline{\mathrm{dadi}}, \underline{\text { bawadi, }}$, and $\underline{\text { inadi, }}$ which are discussed above. In the singable translation below, a translation compensatory strategy has been adopted to accomodate for the rhyming and rhythm loss of the source language song; this strategy is represented in creating a new song that basically preserves the content, sense, and naturalness of the source song, but includes hemistiches' endings that add singability to the translated version. The artist (the singer in our case) knows its basic contours and then, building upon a rigorous apprenticeship in the expectations and possibilities of the tradition, performs it (Sells 1989: 3). This leads us to the expectation that target language audiences 
fail to emulate the source language song as their experience is not only far-fetched, but collides with many physical, albeit environmental components, and spiritual elements such as beliefs and ways of thinking. Before closing, we propose a more refined singable translation, where sense and naturalness are sometimes sacrificed, so as to give the translator the chance to compare and contrast the initial clumsy version with this polished one:

(9) On the dew's trace, oh dear, they rise With firm waists and black-lined eyes

On the top of fountain as doves they land

With blond hair on the shoulders entwined

Gracely, they have passed by alone

Tracing the dew and the chilly breeze of dawn

To dub their hair, the wind has

blown

To their joy, the silk has flown

Similar in height and same age they

start

And as desert deer leisurely they

pace

Follow them, I told you, my heart

As with them come all blessing and grace

The speech they have is that of sign Follow their fancy and never defy

Blame not the lover, alas, oh dear

Aimlessly wandering, and wiping tear

Lovers' moon has become so plain

Sleep not, my eye, till everything I gain

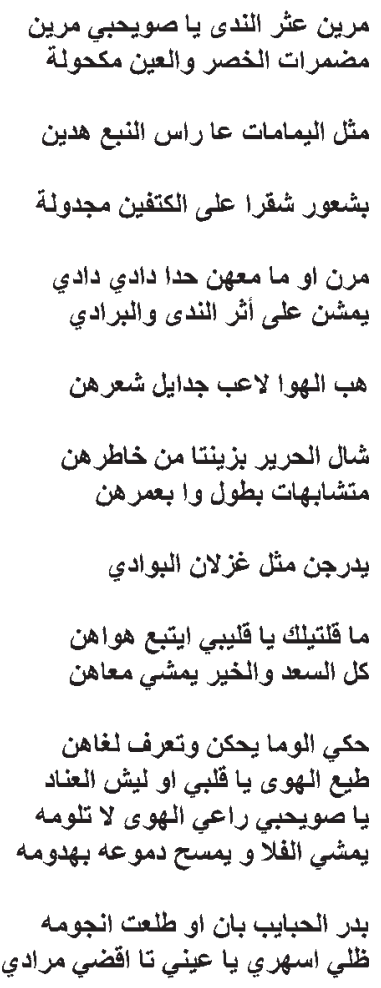

\section{Conclusion}

In the light of the above discussion, the present study has shown that the translation of Jordanian folkloric songs is a challenging task for linguistic, cultural, musical, ecological, emotive and psychological reasons. In general, the foregoing pages reveal that the measurable importance of folkloric songs is notwithstanding, and the style and talents of the individual translator will always play a key role in shaping the translated text. Drawing on Low's (2005a: 185) Pentathlon Approach, the study has also demonstrated some of the key aspects of translating folkloric songs: sense, naturalness, singability, cultural references, and how these elements are interconnected and entangled with each other. All of these aspects must be weighed with respect to the assumed skopos in order to apply the appropriate method of transmission for the individual production, and thus to remain natural and appealing to the target language audience.

The language of Mousa's song chosen for the study has been drawn from the Jordanian folkloric heritage, where the vocalist successfully depicts the daily life 
activities and undertakings in a heightened style, not only through his lucrative choice of diction, but also through escorting this diction with an amazing and striking rebec tune. The analysis has also shown that the existing sharp linguistic and cultural differences between Arabic and English add to the intricacy of translating this type of literature. As far as the content is concerned, the discussion has proved that the source language text is semantically-complex, and the audience of the receptive language can have no more than an artificial face of the coin, which is a shortcoming of translation that can be ascribed to the incompatibilities between the working concept systems of the two languages. Thus, when translating between cultures with different discursive properties, the translator is justified in having a certain leeway when reformulating the lingual-cultural and musical import of the source text for target readers. Another conclusion is that the source text song is colloquiallybased and this provides the composer with enough breadth to play with the feelings of his audience, as the more colloquial a text is, the more attentive it turns out to be. In the attempted translation, however, this aspect is lost as colloquialism is hardly attainable, and if allegedly attained, it would not stimulate similar audience response or effect. Finally, the study makes it clear that the oral composition of the source text gives it credence over its written form in the target language, which consequently confirms that a song is meant to be orally transmitted and not written, as a large meaning of this song seems to be more appreciated when presented in its oral form, the reason for which there has been a serious attempt to produce a singable translation towards the end of the analysis. As such, it is hoped that the paper has succeeded in revealing how Arabic and English differ in the representation of social, cultural, and emotional relations - a lingua-cultural difference that manifests itself strongly in Mousa's song, the subject of this study.

\section{NOTES}

* The authors would like to thank the Research Center of the College of Languages and Translation, Deanship of Scientific Research at King Saud University for their financial support.

\section{REFERENCES}

AL-'Amad, Hanbal (1969): Aghaneena Fil-Diffatil Sharqiyyah Men Al-Urdun. Amman: Dar alThaqafa.

Anderson, Myrdene (2005): The Saami Yoik: Translating Hum, Chant, or/and Song. In: Dinda L. GorléE, ed. Song and Significance: Virtues and Vices of Vocal Translation. Amsterdam: Rodopi, 213-233.

Apter, Ronnie (1985): A Peculiar Burden: Some Technical Problems of Translating Opera for Performance in English. Meta. 30(4):309-319.

Asad, Talal (1986): The Concept of Cultural Translation in British Social Anthropology. In: James Clifford and George E. Marcus, eds. Writing Culture: The Poetics and Politics of Ethnography. Berkeley: University of California Press, 141-164.

Chaume, Frederic (2004): Film Studies and Translation Studies: Two Disciplines at Stake in Audiovisual Translation. Meta. 49(1):12-24.

Clifford, James (1988): The Predicament of Culture: Twentieth-Century Ethnography, Literature, and Art. Cambridge: Harvard University Press.

Clyne, Michael (1994/1996): Inter-Cultural Communication at Work: Cultural Values in Discourse. Cambridge: Cambridge University Press.

Drinker, Henry (1950): On Translating Vocal Texts. The Musical Quarterly. 36(2):225-240. 
Dunbar, Dirk (2002): The Evolution of Rock and Roll: Its Religious and Ecological Themes. Journal of Religion and Popular Culture. 2. Visited on 6 May 2010, <http://www.usask.ca/ relst/jrpc/article-evofrock.html .

Emmons, Shirley (1979): The Art of the Song Recital. New York: Schirmer.

Fernandez, James (1978): Syllogisms of Association: Some Modern Extensions of Austrian Deepsong. In: Richard M. Dorson, ed. Folklore in the Modern World. The Hague: Mouton, 183-206.

Franzon, Johan (2005): Musical Comedy Translation: Fidelity and Format in the Scandinavian My Fair Lady. In: Dinda L. GorléE, ed. Song and Significance: Virtues and Vices of Vocal Translation. Amsterdam: Rodopi, 263-297.

Gerzymisch-Arbogast, Heidrun (2005): Introducing Multidimensional Translation. In: Heidrun Gerzymisch-Arbogast and Sandra Nauert, eds. Challenges of Multidimensional Translation. (EU High Level Scientific Conferences, Marie Curie Euroconferences, Saarbrücken, 2-6 May 2005) Vol. 5. Saarbrücken: Saarland Museum Modern Gallery, 1-15.

Golomb, Harai (2005): Music-linked Translation (MLT) and Mozart's Operas: Theoretical, Textual and Practical Perspectives. In: Dinda L. GorléE, ed. Song and Significance: Virtues and Vices of Vocal Translation. Amsterdam: Rodopi, 121-161.

GorléE, Dinda (1997): Intercode Translation: Words and Music in Opera. Target. 9(2):235-270.

Gorlée, Dinda, ed. (2005): Song and Significance: Virtues and Vices of Vocal Translation. Amsterdam: Rodopi.

Gottlieb, Henrik (2003): Parameters of Translation. Perspectives: Studies in Translatology. 11(3):167-187.

Gottlieb, Henrik (2005): Multidimensional Translation: Semantics turned Semiotics. In: Heidrun Gerzymisch-Arbogast and Sandra NAUert, eds. Challenges of Multidimensional Translation. (EU High Level Scientific Conferences, Marie Curie Euroconferences, Saarbrücken, 2-6 May 2005) Vol. 5. Saarbrücken: Saarland Museum Modern Gallery, 33-61.

Graham, Arthur (1989): A New Look at Recital Song Translation. Translation Review. 29:31-37.

Gudykunst, William and Young, Yun (1992): Communicating with Strangers: An Approach to Intercultural Communication. New York: McGraw-Hill.

Gutt, Ernst-August (2000): Translation and Relevance: Cognition and Context. Manchester: St. Jerome.

Hatim, Basil and Mason, Ian (1990): Discourse and Translator. London: Longman.

Hinton, Leanne, Nichols, Johanna and Ohala, John (1994): Sound Symbolism. Cambridge: Cambridge University Press.

KaIndL, Klaus (2005): The Plurisemiotics of Pop Song Translation: Words, Music, Voice and Image. In: Dinda L. GorLéE, ed. Song and Significance: Virtues and Vices of Vocal Translation. Amsterdam: Rodopi, 235-262.

Langer, Suzanne K. (1953): Feeling and Form. New York: Charles Scribner's Sons.

Low, Peter (2002): Surtitling for Opera: A Specialised Translating Task. Babel. 48(2):97-110.

Low, Peter (2003a): Translating Poetic Songs: An Attempt at a Functional Account of Strategies. Target. 15(1):95-115.

Low, Peter (2003b): Singable Translations of Songs. Perspectives: Studies in Translatology. 11(2):87-103.

Low, Peter (2005a): The Pentathlon Approach to Translating Songs. In: Dinda L. GorLéE, ed. Song and Significance: Virtues and Vices of Vocal Translation. Amsterdam: Rodopi, 185-212.

Low, Peter (2005b): Song Translation. In: Keith Brown, ed. The Elsevier Encyclopedia of Language and Linguistics. Oxford: Elsevier, 511-514.

O'Hagan, Minako (2005): Multidimensional Translation: A Game Plan for Audiovisual Translation in the Age of GILT. In: Heidrun Gerzymisch-Arbogast and Sandra Nauert, eds. Challenges of Multidimensional Translation. (EU High Level Scientific Conferences, Marie Curie Euroconferences, Saarbrücken, 2-6 May 2005) Vol. 5. Saarbrücken: Saarland Museum Modern Gallery, 76-87. 
RAffel, Burton (1986): The Manner of Boyan: Translating Oral Literature. Oral Tradition. 1(1):11-29.

Rosenbaum, Art (1983): Traditional Music and Song in North Georgia. Athens: University of Georgia Press.

SALEH, Ahmed (1978): Influences of Mass Media on Folklore in Egypt. In: Richard M. Dorson, ed. Folklore in the Modern World. The Hague: Mouton, 55-162.

Sells, Michael (1989): Desert Tracings. Middletown: Wesleyan University Press.

ShunnaQ, Abdullah and Abul-Kas, Fayez (1998): Jordanian Folkloric Songs from Arabic into English. Babel. 44(2):150-174.

Spaeth, Sigmund (1915): Translating to Music. The Musical Quarterly. 1:291-298.

Stocks, Michael and Maddock, Andrew (1992): Growing with Music. London: Longman.

Strangways, Arthur Henry Fox (1921): Song-Translating. Music and Letters. 2(3):211-224.

TAGg, Philip (2000): Analyzing Popular Music: Theory, Method, Practice. In: Richard MiddLeton, ed. Reading Pop: Approaches to Textual Analysis in Popular Music. Oxford: Oxford University Press, 71-103.

Whissell, Cynthia (1996): Traditional and Emotional Stylometric Analysis of the Songs of Beatles Paul McCartney and John Lennon. Computers and the Humanities. 30:257-265. 